\title{
Las cofradías del mar en la Corona de Aragón (siglos XIII-XV)*
}

\author{
The sea brotherhoods in the Crown of Aragon \\ (XIII-XV centuries)
}

\author{
JosÉ DAMIÁN GONZÁLEZ ARCE**
}

\begin{abstract}
RESUMEN
Este estudio trata sobre las corporaciones de los oficios relacionados con actividades marítimas en la Corona de Aragón, durante la Edad Media. Los cuales formaron cofradías con fines religiosos, funerarios y mutualistas. Pero dichos oficios regularon su actividad profesional, en los aspectos económicos y laborales, mediante instituciones diferentes a las cofradías como órgano de previsión. Se trató de los gremios o artes, que además gozaron de cierta potestad política.
\end{abstract}

\section{PALABRAS CLAVE}

Corona de Aragón, corporaciones marítimas, gremios, cofradías.

\section{ABSTRACT}

This study treats on the unions of the corporations related to maritime activities in the Crown of Aragon, during the Middle Ages. Which formed confraternities with religious, funeral and mutualists purposes. But the above mentioned trades regulated his professional activity, in the economic and labour aspects, by means of institutions different from the confraternities as organ of forecast. It was a question of the guilds or arts, that in addition they enjoyed certain political legal authority.

\section{KEY WORDS}

Crown of Aragon, marine corporations, guilds, confraternities.

* Fecha de recepción del artículo: 2009-02-26. Fecha de aceptación del artículo: 2009-03-11.

Las reflexiones iniciales sobre este trabajo, González Arce, J.D., 2006 y 2007

** Profesor Contratado Doctor del Departamento de Economía Aplicada, Área de Historia e Instituciones Económicas, Facultad de Economía y Empresa, Universidad de Murcia, Campus de Espinardo, 30100 Murcia. C.e.: josedam@um.es 
El presente trabajo tiene por cometido estudiar la organización de las cofradías de oficios relacionados con el mar en el ámbito de la Corona de Aragón ${ }^{1}$. Para lo cual nos vamos a centrar en el marco de sus dos principales puertos, Barcelona y Valencia, sin dejar de hacer alusiones puntuales a otras localidades. Analizaremos, en primer lugar, las corporaciones laborales que en ellos formaron los trabajadores del mar con objetivo de organizar sus oficios. Para luego pasar al análisis de las cofradías anejas a los mismos, como instituciones paralelas a los gremios que nacieron con la finalidad de atender fines mutualistas, caritativos, religiosos y funerarios.

\section{EVOLUCIÓN CORPORATIVA Y APARICIÓN DE LAS COFRADÍAS}

En las ciudades de Valencia y Barcelona, los oficios reconocidos por el poder político en forma de artes gozaron de preeminencia foral e institucional, y se organizaron formando gremios. Más adelante, algunos de los más importantes vieron aumentar sus competencias y reconocimiento alcanzado la categoría de colegio. Sin embargo, desde un comienzo carecieron de estructura administrativa. Carencia que fue suplida mediante la estructura corporativa de las anexas cofradías de oficio, que contaban con funcionarios, asambleas generales, capillas propias, caja de solidaridad, que a la vez era una caja de préstamo, propiedades, local social y personalidad jurídica; o lo que es lo mismo, eran personas jurídicas con capacidad para recibir donaciones y legados testamentarios. No obstante, ambas instituciones corporativas, oficio y cofradía, no llegaron a confundirse hasta finales del siglo XV, manteniéndose hasta entonces la dialéctica entre el reconocimiento institucionalpolítico del oficio y la presencia jurídico-administrativa de la cofradía. La monarquía trató de frenar el movimiento corporativo separando ambas dimensiones, negando a cada una de ellas el complemento que le faltaba. Por su parte, los prohombres de los oficios intentaron conjugarlas para desarrollar al máximo sus intereses corporativos. De esta forma, las corporaciones laborales obtuvieron el reconocimiento del poder político cuando fueron admitidas en el gobierno urbano y pasaron a designar a sus autoridades internas, en forma de prohombres, pero, cuando estos mismos oficios quisieron ganar en atribuciones organizativas se hubieron de dotar de cofradías anexas, con sus propias autoridades y órganos administrativos, que además de atender a finalidades religioso-asistenciales sirvieron también, en algunos casos, de cobertura a funciones laborales y productivas. Prueba de ello es que en la solicitud de aprobación de los estatutos de más de 20 nuevas cofradías valencianas, en 1392, los representantes de los oficios pidieron al rey que sus mayorales pudiesen tratar los asuntos del oficio, tal y como lo recogían los privilegios de reyes anteriores; que sin embargo, en absoluto hablaban de cofradías y mayorales, sino de oficios y prohombres. Con lo que, probablemente, los artesanos, in-

1 Algunas obras generales sobre el asunto, RUMEU DE ARAMAS, A., 1944; BONNASSIE, P., 1975; IRADIEL MURRGARREN, P., 1993; RIERA I MELIS, A., 1993; BENÍTEZ BOLORINOS, M., 1998. 
tencionadamente, intentasen asimilar las autoridades de la cofradía con las del oficio, buscado con ello una conexión entre política y actividad económica como vía hacia la consolidación gremial (Iradiel Murugarren, P., 1993:263).

Veamos este proceso con arreglo a los gremios marítimos, que, tras su reconocimiento institucional, intentaron ganar protagonismo corporativo fundando cofradías anexas.

\subsection{Barqueros}

Los barqueros de Barcelona fueron el único oficio de esta especialidad de características gremiales en toda la Corona.

Su cometido consistía en llevar las mercancías en barcas, desde los barcos anclados en la rada del puerto, o cerca de la costa, a tierra, y viceversa, cargando y descargando tanto las propias del transporte marítimo como los víveres y otras precisas para las travesías. Se trató de un oficio muy duro que movía a sus practicantes a manifestaciones de solidaridad, como esta de la formación de cofradías, pues ocasionaba un gasto de energía poco común que provocaba un envejecimiento prematuro.

Cuando llegaba un barco al puerto todos los miembros del mismo participaban en el embarque y desembarque de sus mercancías. La paga global la entregaba el patrón del navío a los prohombres de la cofradía, que la repartían a partes iguales entre todos los que habían participado en el trabajo. Para beneficiarse de los socorros mutuos de la cofradía era requisito el haber contribuido a ella al menos durante un año.

Los barqueros de la ciudad contaron con una almoina datada en 1380, bajo la advocación de S. Pedro, con sede en una capilla de la iglesia de S. Agustín. Antes, en 1325 ya fueron emitidas unas ordenanzas que regulaban el oficio. Mientras que en 1350, mediante otra, se revocó la prohibición de que cada barquero no pudiese tener más de un esclavo.

En 1395, el gremio obtuvo un privilegio real mediante el cual se pretendía que se percibiesen los salarios con mayor equidad y puntualidad, para lo que se debía elegir un recaudador, que podía no ser del oficio, quien distribuiría entre los barqueros participantes lo percibido de las labores de estiba y desestiba. Para ello debía confeccionar una lista diaria de los individuos empleados en las mismas, para repartir entre ellos el fondo común, mientras tanto custodiado en el arca de la cofradía por el citado colector. Además, dicho privilegio permitía a los barqueros, en caso de que los dueños de las mercancías no quisiesen abonarles su salario, embargar mercancía por el valor de lo que se les adeudaba. Su salario era variable, en función del estado de la mar durante la carga y descarga, y por tanto del riesgo que corrían realizando su trabajo, teniendo la última palabra sobre este aspecto los 
cónsules de lonja. También ese año 1395, el rey permitió a los barqueros contratar a gentes de fuera del gremio, en caso de que la gran afluencia de barcos o la peligrosidad de la mar así lo aconsejasen, percibiendo éstos su parte de las ganancias colectivas.

El año 1422 los barqueros elevaron a la reina gobernadora una petición para renovar su normativa. En 1453 obtuvieron nuevos privilegios reales, entre ellos los siguientes: ningún barquero podía comenzar la desestiba de un barco sin esperar a los restantes, para así repartirse el trabajo; se seguiría apuntando, ahora por parte de un fiel, quiénes trabajaban a diario, para que los prohombres hicieran el reparto de los beneficios, en tanto que el dinero sería percibido por dos «cobradores», que lo debían entregar a los prohombres, quienes designarían a los barqueros que debían acudir a cargar y descargar cada barco.

Finalmente, en 1495 estos barqueros de San Pedro redactaron nuevas ordenanzas, aprobadas por el virrey de Cataluña: posibilidad de contar con mozos o mancebos que ayudasen en la estiba-desestiba, que percibirían parte de las ganancias colectivas y participarían en los auxilios por vejez o enfermedad, así como en los beneficios funerarios, al contribuir a la caja de la almoina; poder exigir exámenes a quienes pretendiesen el acceso al gremio, por parte de los prohombres y peritos, que comprobarían la robustez, salud, capacidad e idoneidad del candidato, que no podía tener más de 40 años (se aclara aquí que el gremio o arte era algo diferenciado de la cofradía o almoina, por lo que el ingreso en ésta no implicaba el acceso automático al primero, de ahí la necesidad de examen); dicho candidato, por ingreso, debía abonar una tasa de 1 florín de oro aragonés, prestar juramento y servir en el gremio durante al menos un año para beneficiarse de los socorros mutuos.

Por su parte, los barqueros nuevos se dirigieron al rey Juan II, en 1459, solicitando una cofradía propia, pues carecían de ella; la cual situaron bajo la advocación de la Virgen de la Consolación, en el monasterio de los franciscanos. Según sus ordenanzas, entre otros aspectos que veremos, establecieron un arca pía, podían reunirse en cabildo cuando lo estimasen oportuno y crearon un fondo común para hacer frente a las indemnizaciones que tuviesen que afrontar ${ }^{2}$.

\subsection{Estibadores}

Un gremio diferente al de barqueros fue el de bastaixos, bastages, palanquines, mozos de cuerda o estibadores. La labor de estos trajineros barceloneses consistía en el acarreo y colocación de las mercancías en los barcos o en tierra,

2 TINTÓ SALA, M., 1992; BORRÁS y VICTORIO, 1990:158-159; BONNASSIE, P., 1975:130; BOFARULL Y DE SARTORIO, M. de, 1876:144; BOFARULL Y SANS, F. de, 1910:316-323; CAPMANY Y DE MONTPALAU, A., 1779:I, 858-862, II, 380-382, 533-535, 554-557, 617-619; DURÁN Y SANPERE, A., 1959:200-206. 
para depositarlas o cargarlas de los almacenes donde iban a ser, o estaban, guardadas o de las barcas que las trasladaban a aquéllos o a los almacenes de tierra. Este oficio que en origen hubo de ser desempeñado por esclavos, como indica su nombre (macips de ribera), a comienzos del siglo XV estaba formado por un gremio de hombres libres, con unas ordenanzas reformadas por Alfonso $\mathrm{V}$, en 1418; momento en el que este rey les concedió nuevos privilegios y les confirmó los que ya tenían. En 1432 se dispuso que ningún esclavo pudiese ejercer el oficio de trajinar en el muelle, aunque sí podían trabajar para sus respectivos dueños, que debían ponerles grilletes en caso de que fuesen infieles y no podían alquilarlos a otros si no tenían carta de libertad o no estaban casados. Los esclavos no podían vivir solos, sino con otro compañero, salvo si tenían mujer propia. En 1433, mediante unas ordenanzas, se les consintió poder elegir prohombres del oficio, en el número que estimasen convenientes. Los cuales tendrían las tres llaves de la caja de la almoina, que no podía ser abierta sino en presencia de diez o doce macips. Los prohombres debían poner en manos de alguien ajeno un libro de papel con los datos y recibos de la caja; cuando los mismos finalizasen su regimiento debían rendir cuentas. Los macips se dividían entre mayores, medianos y menores, y pagaban, respectivamente, 3, 2 ó 1 sueldos de entrada a la cofradía, más 2 dineros semanales; también a la caja irían los dineros sobrantes del pico de las ganancias que no se pudieran repartir de forma equitativa entre todos; se anotaría los que pagaban; y, si alguno caía enfermo y era pobre, se le ayudaría de la caja. En 1441 se dispuso que la opinión de 3 de los prohombres prevalecería en la toma de decisiones. Más adelante solamente fueron designados 3 prohombres (en cuya elección tomarían parte sólo palanquines con domicilio propio y con esposa, o viudos, no amancebados), por lo que prevalecería la opinión de dos de ellos.

Dicho gremio tenía aneja una cofradía bajo advocación de Santa Catalina, en Santa María del Mar, formada por cristianos de la Centura o Cintura, a la que pagaban un dinero para poder trajinar. Sin embargo, en 1439 los macips jóvenes de la ribera establecieron una almoina bajo la advocación de San Maciá y Santa Tecla, a la que debían donar 3 dineros semanales, al margen de la arriba vista de Santa Catalina. Los jóvenes de la almoina que quisiesen ingresar en esta última cofradía y no fuesen cristianos de la Centura debían abonar 1 dinero a la misma y 3 a la limosna (almoina). Los enfermos serían asistidos por 12 macips designados por los prohombres; se tenía obligación de asistir a los sepelios, así como a la procesión del Corpus, al igual que acompañar a los prohombres a las vísperas y fiestas de S. Maciá y Santa Tecla. Esta almoina renovó sus ordenanzas en 1445, obligando a sus miembros a ingresar en la cofradía de Santa Catalina de los cristianos de la Centura, y viceversa. Todos debían contribuir a las tres festividades, en cada una habría una misa mayor en el altar de Santa María del Mar; en el Corpus se haría una sola luminaria, y en el cirio mayor habría 4 imágenes, la Virgen, Santa Tecla, Santa Catalina, y en el centro de las tres, San Maciá; serían nombrados 3 prohombres y 10 jurados, 6 de ellos casados; los prohombres, sin la intervención de los jurados, solamente podían gastar 10 sueldos. 
Nuevas ordenanzas fueron confirmadas por Fernando el Católico, en 1513: Que sólo los miembros de la cofradía pudiesen ejercer de palanquines; que pudiesen hacerlo a cualquier hora sin ser privados de su oficio; que los deudores de la cofradía no pudiesen ser prohombres; que tras estar fuera de la ciudad, se pagasen las cuotas impagadas; que se pudiesen fijar las cuotas para culto y ayudas mutuas; y que pudiesen tener una sede gremial ${ }^{3}$.

\subsection{Calafates}

Los maestros de hacha y calafates de Barcelona tenían por trabajo la construcción y reparación de barcos, estando divididos en dos grandes grupos: los maestros de hacha que trabajaban en tierra, en los barcos del puerto o en el bosque, escogiendo los troncos más aptos; y un segundo grupo que estaba formado por aquellos maestros que se embarcaban para realizar las reparaciones precisas durante la navegación. Todos ellos, puede que también los embarcados, trabajaban bajo la dirección de un maestro mayor, responsable de la obra de construcción o de reparación de la nave, que dirigía el trabajo y fijaba el salario de sus adjuntos. La movilidad de estos trabajadores cuando estaban embarcados, como la de los

3 Antes de constituir su cofradía, estos trabajadores ya realizaron ciertas actividades pías, como entre 1329 y 1383, cuando ayudaron a transportar las piedras para la construcción de Santa María del Mar, sin percibir nada a cambio. Lo que les valió que gozasen de privilegios especiales en dicha iglesia, como el que los prohombres de la cofradía guardasen las llaves del tabernáculo, o que los cofrades a los que se iban a administrar los sacramentos fuesen recibidos como altos dignatarios (CAPMANY Y DE MONTPALAU, A., 1779:I, 395-396, II, 421-422; CAPMANY, A., 1933:14-36; MARTÍN GRANIZO, L., 1950: III, 25; BONNASSIE, P., 1975:123; BORRÁS y VICTORIO, 1990:157-158). Otra cofradía de palanquines hubo en Valencia, hacia 1393, la de los bastexes del grao (estibadores del puerto) (BENÍTEZ BOLORINOS, M., 1998:19). En 1505, los marinos de Palma de Mallorca se dirigieron al rey Fernando con la intención de regular el oficio de descargadores de la ribera. Para ello argumentaron que una de las cosas que más beneficiaban al reino de Mallorca era el arte de la mercadería, y en ella el comercio de ropas y otros bienes; a cuya carga y descarga se venían dedicando ciertas personas, vulgarmente llamados descarregadors, tal y como los había en las ciudades y playas de Barcelona y Valencia. En las citadas ciudades había 2 mayorales que en las labores de estiba y desestiba recaudaban el dinero que luego repartían entre los participantes, como hemos visto. Sin embargo, en Mallorca, por falta de hombres de mar, los descargadores eran payeses y menestrales que debían ser regidos por marinos con experiencia en el arte del mar, encargados de recibir los peculios y luego repartirlos entre los estibadores. Por dicho motivo, los clavarios y sobreposats de la caja de los marinos, que argumentaban se había constituido en tiempos de la conquista del reino, y a quien correspondía velar por el orden y beneficio de toda la ribera marina, suplicaron al rey que decretase las ordenanzas que le presentaban, aprobadas por los citados clavarios y la cofradía de la caja de los citados marineros. Las cuales, entre otras cosas, disponen que los clavarios o sobreposats anuales, al día siguiente de ser elegidos, debían designar dos hombres buenos entendidos en las cosas de la mar encargados de administrar las tareas relativas a la carga y descarga del puerto y riberas mallorquinas, tanto en tierra como en el mar. Los cuales serían los receptores de los emolumentos de la estiba y desestiba. Para lo cual debían estar uno dentro de la nave y el otro en tierra, para que los dueños de las mercancías pagasen todo lo que debían. Los receptores debían jurar que repartirían los dineros, dando a cada uno lo que le pertenecía, así como su porción de las ganancias a la cofradía y caja de los marineros, según era costumbre. Los estibadores que no quisiesen someterse al control de los receptores serían expulsados del oficio. Los barqueros que actuasen por su cuenta, cargando y descargando, debían asimismo entregar sus recaudaciones a los receptores, para su administración como los demás (SANXO, P.A., 1895:217-219). 
barqueros, hizo que entre las ordenanzas de sus cofradías se contasen cláusulas relativas a su rescate en caso de que fuesen cautivados por sarracenos.

La cofradía de carpinteros de ribera de Barcelona, o calafates, dedicada a Santa Catalina, data de 1392, con ordenanzas de contenido técnico, profesional, religioso y piadoso; siendo elegidos conjuntamente los regidores de la cofradía, prohombres, y los de la corporación, cónsules. Al menos desde el año anterior, 1391, dos de sus miembros formaban parte de los representantes de los gremios en el consejo municipal ${ }^{4}$.

Entre las cofradías documentadas en Valencia, hacia 1392 se encuentra la de calafates, existente ya en 1306. Año en el que fue aprobada por Jaime II y ubicada en el convento de la Trinidad, al que iban a parar parte de las contribuciones sus miembros. La cual fue dotada de la facultad de elegir dos hombres buenos del oficio que pudieran regirlo con consejo de los miembros del mismo, para su utilidad ${ }^{5}$. Dichos calafates suplicaron al rey, el citado año $1392^{6}$, que les confirmase unas nuevas ordenanzas: concediendo poder a los mayorales de la almoina para apartar de la cofradía a quienes no pagasen las contribuciones; que éstos pudiesen obligar a los cofrades a acudir al entierro de un compañero difunto; y, que sólo estuviesen obligados a trabajar para el rey en sus barcos.

\subsection{Pescadores}

Tras la conquista, en 1238 Jaime I informó al Común de Pescadores de la Ciudad de Valencia que se había reservado para sus rentas los derechos derivados de la Albufera. Posteriormente, en 1250 otorgó un privilegio dando libertad de pesca en Valencia, pero reteniendo el $10 \%$ de lo pescado en el mar y el $5 \%$ de la Albufera. El citado Común era una especie de corporación inicial que agrupaba y representaba a todos los pescadores de la localidad. La primera regulación conocida de los pescadores es una disposición de Pedro III de 1283 instituyendo cuatro hombres buenos, elegidos anualmente por el bayle y el arrendatario del quinto real, para que regulasen las pesquerías de la Albufera, con tal autonomía y jurisdicción en el ámbito del oficio que los podemos considerar con competencias gremiales. En 1337 Pedro IV ordenaba guardar las ordenanzas establecidas para el buen go-

4 BORRÁS y VICTORIO, 1990:556-557; RUMEU DE ARMAS, A., 1944:546; BOFARULL Y DE SARTORIO, M. de, 1876:353-366. Desde temprano, los reyes designaron a los calafates reales del puerto de Barcelona, con el cometido de actuar como maestros mayores calafates en las obras de reparación de las galeras y leños reales. Así por ejemplo, en 1310 Jaime II concedió el oficio de por vida a Pedro de Ripa, calafate barcelonés (Museo Naval de Madrid [MNM] Manuscritos [Mss.], 366, 223r).

5 BOFARULL Y DE SARTORIO, M. de, 1876:35-37; RUMEU DE ARMAS, A., 1944:552; UÑA SARTHOU, J., 1900:143; BENÍTEZ BOLORINOS, M., 1998:17-19. En unas ordenanzas de 1424 quedó prohibido al oficio y cofradía de carpinteros enseñar su arte a musulmán, judío o infiel, para que al volver a su tierra no pudiesen construir embarcaciones (GUIRAL-HADZIIOSSIF, J., 1989:226).

6 Archivo de la Corona de Aragón (ACA), Cancillería, Registros, 1.903, 115r-116r; MNM, Mss., 366, 279r-280r. 
bierno de la Albufera por privilegios de reyes anteriores (Pedro III, Jaime II y Alfonso III), entre las que se ratificaba la potestad de los cuatro hombres buenos, ahora llamados por vez primera «jurados», para regular todo lo relativo a las pesquerías, sin cobrar salario alguno y sin redactar documentos, según la costumbre antigua. Sus decisiones podían ser recurridas ante el bayle, ante quien debían jurar su cargo al ser nombrados. En la confirmación de sus privilegios, hecha por el infante don Juan, en 1377, a petición de los pescadores de la Albufera, se aclara que los cuatro jurados elegidos por los mismos cada año para regularlos tenían atribuciones penales, con consejo del bayle. Además, podían conocer todas las cuestiones que surgiesen entre los pescadores, brevemente, sin escrito y sin cobrar derechos. Los pescadores se regirían por las costumbres de los tiempos de dominio musulmán, no recogidas en ninguna escritura, tenidas entre ellos y no provenientes del derecho común ni de ley paccionada alguna de la tierra. El justicia no podía ejercer ninguna jurisdicción sobre ellos, y se aclara que tampoco la tenía el almotacén 7 .

A estos privilegios se refiere el colegio pescadores de la Albufera en 1382 cuando solicitó del entonces infante don Juan su confirmación. Además, elevaron una serie de quejas contra los pescadores del mar o de afuera, puesto que éstos, años atrás, habían fundado su propio colegio y tenían sus propios jurados, diferentes a los de la Albufera, cuando con anterioridad habían pertenecido, según dichos privilegios reales, al colegio de los pescadores de la misma. Pertenencia que finalmente ratificó el infante. Sin embargo, previamente, en 1378 el bayle proveyó que los tres jurados de la Albufera no se entrometiesen en las cuestiones de los pescadores del mar, bajo pena de 200 moravetinos, reservando su conocimiento al propio bayle y a los jurados de los pescadores del mar; sin duda ésta sería la causa para la breve escisión corporativa de estos pescadores, a la que se puso fin mediante la intervención del infante Juan, antes vista ${ }^{8}$. De nuevo, en 1393 solicitaron los de la Albufera, del entonces ya rey Juan I, la confirmación de sus privilegios, libertades y franquezas, tal y como los habían ratificado los reyes precedentes. Ese año le pidieron, además, que aprobase nuevas disposiciones, relativas a las artes y lugares de pesca, a la reunión de los miembros del Común, a las tasas a pagar y a la potestad de los jurados, que también afectaban a los pescadores de Cullera, Sueca y Catarroja (o del mar), al nombramiento de 25 hombres buenos consejeros de los jurados, 5 de ellos pescadores de fuera, y al precio y calidad de la sal (Bofarull y Sans, F. de, 1910:78-86; Freire Moliner, M.J., 1995:82-86).

7 CARUANA TOMÁS, C., 1954:17-46; SALCEDO FERRÁNDIZ, S., 1957:15-21; SANMARTÍN ARCE, R., 1982:219-229; RAMÓN FERNÁNDEZ, F., 2001:15-19, 94-96; GUIRAL-HADZIIOSSIF, J., 1989:471479; BENÍTEZ BOLORINOS, M., 1998:17-19. En 1368, Pedro IV concedió a los jurados y comunidad de pescadores del mar y la Albufera de Valencia la facultad para nombrar síndico y procurador; y, según los propios pescadores, en la relación de privilegios que presentaron ante su hijo, el infante don Juan, en 1377, antes citada, también la facultad de constituir colegio; término que aparece ya en un documento real de 1382, que a continuación veremos (FREIRE MOLINER, M.J., 1995:36-37, 53-63).

${ }^{8}$ MNM, Mss., 366, 269r-271r; FREIRE MOLINER, M.J., 1995:71-74; CARUANA TOMÁS, C., 1954:26, 190-191. 
En 1404, Martín I, en un documento de confirmación de los privilegios de los pescadores, que es considerado como la primera mención del Común en forma de derecho positivo, atribuye a los jurados la aplicación y modificación de las ordenanzas de la Albufera, bajo la aprobación del bayle. Además, les consintió cobrar tasas siempre que interviniesen en asuntos concernientes a personas ajenas al Común, de las que llevarían estos derechos. Así como portar armas, como otros oficiales reales, con las que remarcar su jurisdicción. También da cuenta de nuevas pretensiones de segregación por parte de los pescadores del mar, que querían nombrar jurados propios; a lo que contestaron los de la Albufera solicitando del rey que se penase a los mismos si lo intentaban, para ello alegaron que en caso de división entre los trabajadores surgían discordias, como lo ocurrido cuando los pelaires se dividieron en dos cofradías. No obstante, ya en el siglo XV, dentro de la misma Comunidad parece que pudo haber dos tipos de jurados diferentes, los de la Albufera y los del mar. En 1415 Fernando I emitió un privilegio aprobando varias ordenanzas para la Albufera y confirmando las anteriores, a la vez que disponía que los cuatro jurados del Común de los pescadores pudiesen conocer todas las cuestiones que pudiesen suceder entre los mismos, tanto de la Albufera como del mar. Igualmente concedió al Común la ratificación de sus privilegios, como el de que se pudiesen reunir en su sede gremial de la parroquia de San Andrés, en la calle de les Parres y que los jurados conociesen las cuestiones del oficio, del mar y de la Albufera, sin intromisión del almotacén. También recordó que los pescadores del mar jamás se podrían separar de los de la Albufera y debían contribuir en todas las cosas del Común, tal y como se venía haciendo desde tiempos de la conquista (Freire Moliner, M.J., 1995:95-107, 113-128; Caruana Tomás, C., 1954:28-33, 135-138).

Este colegio o Común de los pescadores contó con una anexa cofradía, una institución paralela al gremio de carácter social. De ella se sabía que existía ya hacia 1392 (Benítez Bolorinos, M., 1998:19). Pero ahora la podemos documentar en $1308^{9}$, año en el que fue fundada por Jaime II, con sede en el convento de la Trinidad. Quien concedió a los pescadores los mismos estatutos que dos años antes a los marineros ${ }^{10}$. Que a su vez los habían obtenido idénticos a los que este rey diera meses antes a los calafates de la ciudad, autorizando la constitución de su cofradía (Bofarull y De Sartorio, M. de, 1876:35-37), tal y como hemos visto más arriba. También permitió cobrar tasas a los miembros del oficio con destino al convento de trinitarios, a obras pías o para fines funerarios. Quedó prohibido que hiciesen coaliciones, confederaciones, juras ni ordenanzas sin autorización real. El citado año 1392 los pescadores valencianos se dirigieron al rey al que presentaron unas nuevas ordenanzas hechas por los prohombres de la cofradía para su gobierno, colocando su cofradía bajo la protección de San Andrés ${ }^{11}$.

\footnotetext{
9 ACA, Cancillería, Registros, 205, 198v; MNM, Mss., 366, 221r-222r.

10 ACA, Cancillería, Registros, 203, 243v; MNM, Mss., 366, 219r-220r.

11 ACA, Cancillería, Registros, 1.903, 166r-168v; MNM, Mss., 366, 281r-283v.
} 
Otra cofradía o hermandad de pescadores valencianos se documenta hacia comienzos del siglo XVI, ésta más vinculada con el Común, como veremos, y dedicada a la Virgen de la Bona Via. Nació con el cometido de imponer penas por faenar los días festivos, tanto a los cofrades como a los no miembros, especialmente los dedicados a la Virgen; las cuales tenían como destino, en parte, la capilla de la Verge María de Bona Via, edificada en la casa del gremio, la otra mitad de las penas iba destinada a las arcas reales. Dicha pesca en días feriados estaba asimismo prohibida igualmente más allá de los términos de Cullera y el Puig (Freire Moliner, M.J., 1995:178-181).

De los pescadores barceloneses se han conservado escasas noticias. Como los barqueros y calafates, también entre las ordenanzas de su cofradía las hubo relativas a rescates, aunque solamente cuando navegaban en barcos de pesca, esto es, durante el ejercicio de su profesión. Se pagaban 30 libras por cada pescador apresado por los moros, 15 si lo era por otros corsarios. En caso de que los fondos de la caja de la cofradía fuesen insuficientes, los cónsules y prohombres podían hacer trabajar con este cometido a todos los miembros del oficio hasta reunir el dinero. Cuando la barca del pescador era capturada, siendo nueva, se preveía una indemnización especial a criterio de los prohombres, que podía llegar a 15 libras $^{12}$.

\subsection{Marineros y navegantes}

Si bien la primera mención a los cónsules de mar de Barcelona (1301) hace referencia todavía a funcionarios municipales, y no aún gremiales, es posible que existiese anteriormente una especie de consulado, o mejor una universidad, en virtud de unas cartas de Jaime I de 1257, quien instituyó un Consejo o Universidad de Prohombres de la Ribera, propietarios de barcos, con encargo de redactar ordenanzas para el gobierno del puerto, dos de los cuales actuaban como árbitros en las controversias jurídicas. También tenían facultad de elegir un jefe o Caput ma-

12 BONNASSIE, P., 1975:135. Otra localidad catalana que contó con una cofradía de pescadores fue Tortosa. La llamada de San Pedro, que es una de las cofradías gremiales de mayor antigüedad, ya que el año 1116 llegó a una concordia con la ciudad en la que se radicaba, destinada a poner fin a una serie de diferencias entre ambas, relativas a ciertas exenciones en las tasas municipales (FOGUET MARSAL, J., $1923: 38$ y 81 y ss.). Otra cofradía de pescadores, bajo advocación de San Nicolás, hubo en esta localidad, según un documento de 1372 (SANCHO SERAL, M.L., 1925:33). Una última fue constituida en 1430 , en este caso junto con los marinos de la localidad, con autorización de la reina gobernadora, María de Castilla, y sede en el monasterio de los frailes menores, con la finalidad de recaudar fondos entre sus miembros para el rescate de cautivos caídos en poder de los berberiscos (ACA, Cancillería, Registros, 2.596, 12r-v; MNM, Mss., 366, 297r-v). De los pescadores mallorquines se puede apuntar que su gremio se remontaría a 1354, aunque puede que a poco de la conquista de la isla los mismos ya se reuniesen para deliberar sobre sus asuntos. Su sede era la iglesia de su patrón, San Pedro apóstol, donde era dicha una misa diaria. Hacia 1459 los pescadores contarían con una organización similar a las otras cofradías de la isla, con sobreposats, prohoms y otras figuras similares (ENSENYANT PUJOL, G., 1991:248-249; QUETGLAS GAYÁ, B., 1939:185-187; RUMEU DE ARMAS, A., 1944:154; DEYÁ BAUZÁ, M.J., 2005:1.031). 
jor y establecer junto a él ordenanzas destinadas a la custodia y conservación de la Ribera, así como a su defensa armada, para lo que podían disponer la recaudación de contribuciones y cuotas. Actuaron por tanto como un auténtico gremio, con potestad policial, normativa y probablemente judicial, con un fuerte espíritu de hermandad, que unía a todos los mercaderes y gentes de mar a través de un juramento prestado ante el rey y ante sus representantes, lo que se traducía en una protección mutua que se debían dispensar todas las naves. Sus estatutos fueron promulgados en 1258 , sin que se pueda concluir de forma absoluta que este consejo fuese el antecedente del Consolat del Mar, decretado en 1347.

Anterior en el tiempo fue el de Valencia. Ciudad que recibió el primero de los privilegios consulares otorgados por los reyes de Aragón, en 1283. Dicho privilegio de Pedro III es una breve carta que contiene apenas la forma de designación de los dos jueces consulares, elegidos anualmente, en la víspera de Navidad, por la mayoría de los hombres buenos del mar (marineros, patrones y navegantes), reunidos en consejo en la iglesia de Santa Tecla de la ciudad de Valencia, para ser presentados en la catedral ante el rey o su representante, el batlle, y jurar en presencia de la justicia de la ciudad que desempeñarían bien y fielmente el oficio del consulado. Los elegidos debían ser conocedores del arte del mar, estando en un principio excluidos todos los que no fuesen hombres del mismo (hasta 1358 no entró en el consulado un comerciante, porque la peste había diezmado a los marinos y navegantes), y determinar los contratos y disensiones entre los hombres del mar y los mercaderes, según las usanzas y costumbres del mar de la ciudad de Barcelona (las ordenanzas arriba vistas). Caben dudas a la hora de interpretar esta disposición como la posibilidad de que un gremio de marineros y navegantes eligiese a sus representantes en fecha tan temprana, pues al parecer los hombres buenos serían un comité de los marineros y armadores más selectos designado por la municipalidad para organizar el tribunal, aunque las formas ya son muy cercanas a lo que sería el antecedente de un gremio de hombres del mar. Este procedimiento de elección, aunque varió en el tiempo, fue incorporado a las ordenanzas del Consulado del Mar que con el tiempo compartieron, además de Valencia, las otras ciudades que contaron con esta institución. Un mes más tarde, en enero de 1284, estando de nuevo el rey en Valencia, amplió estas concesiones, permitió construir una barraca en el Grau donde guardar los aparejos navales, constituirse en gremio o cofradía (facere comune) y recaudar dinero para mantener dicha barraca y otras necesidades. Este Consulado se aclaró que era exclusivo de Valencia, y no podía extenderse a otras corporaciones locales del reino ${ }^{13}$.

En 1306, Jaime Il fundó en el convento de los franciscanos de Valencia la cofradía de marineros de San Pedro ${ }^{14}$, mediante un diploma prácticamente igual al que autorizaba meses antes la constitución de la cofradía de calafates de la ciudad

13 SMITH, R.S., 1978:29-30 y 163; CAPMANY Y DE MONTPALAU, A., 1779, II:25-30; 1990:465 y 497; GONZÁLEZ DÍEZ, E., 1994:19-20; FONT RIUS, J.M., 1965:XXXIX-XXXV.

14 ACA, Cancillería, Registros, 203, 243v; MNM, Mss., 366, 219r-220r. 
y al que dos años después daría nacimiento a la de pescadores, ambas más arriba vistas. A la misma, como a las anteriores, le permitió la elección de dos o más hombres buenos anuales para gobernarla con consejo de la mayor parte de sus miembros, siempre que no atentasen contra los intereses reales o el poder de sus oficiales. Éstos tuvieron por cometido, asimismo, entender en las discordias surgidas entre los miembros de la cofradía e incluso con los de fuera, por lo tanto potestad policial y judicial sobre todo el oficio. Si se reunían 10 miembros o más de la cofradía podían redactar aquellos estatutos que estimasen convenientes. Anualmente se podían cobrar cuotas a los cofrades, con las que contribuir al convento en el que tenían la sede, así como ayudar a los caídos en la pobreza o a los gastos funerarios. Finalmente, como a los pescadores del mar, les prohibió hacer coaliciones, juras y ordenanzas sin autorización real, dentro de su política de represión de este tipo de asociaciones ilícitas que en parte también puso limites al corporativismo gremial (González Arce, J.D., 2008: 15-17).

Como las anteriormente vistas cofradías de calafates y pescadores valencianas, esta de marineros se renovó, aprovechando las facilidades dadas por Juan I para la fundación de nuevas cofradías profesionales y la reforma de los estatutos de las existentes. De forma que, en 1392 dicho rey aprobó las ordenanzas de una reconstituida cofradía de marineros ${ }^{15}$, que debía ser denominada como «la almoyna dels homens de mar», ahora bajo la advocación de san Esteban, según se contiene en el articulado de las nuevas ordenanzas, y no ya bajo S. Pedro, como la inicialmente aprobada por Jaime II, a la que se alude en el prólogo de la aprobación de Juan I y en el preámbulo de las citadas ordenanzas; aunque, también en dicho preámbulo, se cita a Santo Domingo como patrón de la misma. La cual se ubicaría en el convento de los frailes predicadores, donde celebraría sus actos religiosos y comidas confraternales. Es de destacar que, en el aludido preámbulo, además de la correspondiente invocatio a la divinidad y de la exposición de moti-

15 ACA, Cancillería, Registros, 1.903, 172v-177r. El gremio de los mareantes matriculados dedicados a la navegación, y a la carga y descarga, habría sido fundado en Mallorca por Jaime II, en 1310, colocándose bajo la advocación de San Telmo, para el que celebraban una fiesta el siguiente domingo tras la natividad de $\mathrm{S}$. Juan Bautista, en su propia capilla, sita en la esquina de la calle del Mar (ENSENYANT PUJOL, G., 1991:248-249; QUETGLAS GAYÁ, B., 1939:145-146; RUMEU DE ARMAS, A., 1944: 154). Sin embargo, en las ordenanzas de 1506 redactadas por esta cofradía para regular el oficio de los descargadores del puerto y ribera, que más arriba hemos visto, se dice que esta caja de marineros, con su clavario y sobreposats, fue constituida en tiempos «de la adquisició del dit regne» (SANXO, P.A., 1895:217-219). Otra asociación de marinos se radicó en Coplliure, en el Rosellón. Agrupaba a patrones y marineros de galeras, leños y otras naves, habitantes en la villa. Sus ordenanzas fueron aprobadas por Juan I en 1388, y, según se contiene en el preámbulo de las mismas, la cofradía se remontaría 40 años atrás, desde cuando se venían observando las prácticas ahora presentadas como ordenanzas para su aprobación. Las cuales ya habrían sido autorizadas por el padre del citado rey, Pedro IV, y consistían en la constitución de una caja de la almoina y recaudar fondos entre los navegantes para fines piadosos (BOFARULL Y DE SARTORIO, M. de, 1876:289-293). Una última cofradía de navegantes fue la formada por los marinos barceloneses en 1450 muy similar a la más arriba vista de marinos y pescadores, fundada en 1430, en Tortosa, para el rescate de cautivos, pues compartía con ésta ese mismo fin. Para ello, como aquélla, la cofradía barcelonesa podía recaudar entre sus socios dinero para el rescate de marinos y otros en poder de sarracenos, así como destinar, para tal fin, lo recaudado en forma de penas y multas (ACA, Cancillería, Registros, 2.546, 21r-22r). 
vos que llevaron a la redacción de esta nueva normativa, junto con la nueva intitulación de la cofradía antes referida, se contienen los nombres de sus componentes: además de los dos mayorales del año 1392, junto a los salientes del año anterior, que fueron los que presentaron al rey, para su aprobación, los nuevos estatutos, los de otros 47 cofrades, que en su mayor parte serían marineros o dueños de embarcaciones del puerto de Valencia.

\section{ANÁLISIS DE LAS COFRADÍAS}

Generalmente, las ordenanzas constitucionales de los gremios y cofradías gremiales comienzan por un prólogo, donde consta la aprobación de las mismas, y por tanto del correspondiente gremio o cofradía, por la autoridad pertinente (sobre todo real), tras el cual se contienen las ordenanzas propiamente dichas. Que principian con un preámbulo, que consta de una invocación (invocatio) a la divinidad; la exposición (expositio) de motivos de la constitución de la corporación, también buscando el servicio divino, a veces real y público; así como la colocación de dicha corporación bajo la protección general de Dios, la Virgen y los santos, y en especial bajo la advocación de alguno de ellos relacionado con la profesión. Luego se sigue el articulado, o cláusulas de las ordenanzas, donde se contienen los elementos expositivos o de obligado cumplimiento por los socios. Las hubo de tres clases, organizativas, encaminadas a fijar las normas de funcionamiento de la asociación; sociales, a regular las cuestiones religiosas y mutualistas; y económicas, para articular el funcionamiento del oficio en lo laboral y productivo.

\subsection{Aspectos organizativos}

Quienes quisiesen ingresar en la cofradía de los barqueros de Barcelona debían ser inscritos en su libro-registro, contribuyendo a los gastos de mantener encendidos los cirios y lámparas y otros de la capilla. Para ello pagarían todas las semanas, el sábado, un dinero por ellos mismos, más otro tanto por cada criado o esclavo que tuviesen. Los administradores de los fondos serían cuatro prohombres del oficio elegidos por el mismo, durante un año. Dichos administradores debían encargar la custodia de los caudales de la cofradía, o bolsa, a dos hombres buenos cada mes, en pena de ser sancionados con una libra de cera si no aceptaban, excepto por causa justificada, caso en que se pasaría este cometido a otro hombre bueno. El día de S. Pedro todos los barqueros se juntaban en el monasterio de $\mathrm{S}$. Agustín a comer y pagaba cada uno 2 sueldos, lo restante necesario para sufragar los gastos de la comida salía de la caja de la almoina, a criterio de los cuatro administradores, los que no acudiesen a la comida sin tener excusa razonable serían multados con 2 sueldos y 6 dineros. Los barqueros nuevos, en 1459, dispusieron como fiesta la de la Consolación y como vicario de su cofradía a un maestro de teología del monasterio de S. Francisco, en cuyo altar mayor tenía su sede la misma. 
Todos tenían como obligación acudir a la fiesta de su patrona, tanto a los oficios de las vísperas como a la misa del día festivo, en pena de una libra de cera. Las cuotas a pagar por dichos barqueros nuevos a la caja de su cofradía, según sus ordenanzas, ascendían a 2 sueldos, si les correspondían de las mercancías cargadas-descargadas hasta 40 , en caso de tratarse de un barco; si se trataba de un leño, hasta 20 sueldos, 1 sueldo. Si los nuevos, o de Santa María, descargaban las mercancías junto a los otros barqueros, o de S. Pedro, unos las de popa y los otros las de proa, debían ingresar en la caja 6 dineros, más la cantidad que restase de pico, siempre que no llegase a 1 dinero por cabeza en el repartimiento. Estos fondos se dividían en tres partes, custodiadas por el prohombre de la cofradía, por dos administradores patrones y, la tercera, por los dos administradores no patrones. Aquéllos que quisiesen entrar en la cofradía sin ser barqueros, hombres o mujeres, debían abonar una cuota inicial de 1 sueldo y 1 dinero, así como 1 sueldo anual; mientras que los que tuviesen barca para trabajar en el oficio pagarían de entrada 1 maravedí de 9 sueldos.

De manera similar, a la cofradía de calafates barceloneses, según sus ordenanzas de 1392, podían pertenecer todos los maestros de hacha, sus mujeres, hijos y compañeros. Para cubrir los fines píos y caritativos de la misma cada maestro pagaría de entrada 4 sueldos. Además, daría semanalmente, también a la caja, 2 dineros. Sus familiares sólo darían aquello que graciosamente quisiesen, en el caso de los hijos, lo que sus padres prometiesen por ellos. Estos dineros debían ser semanalmente recaudados por los dos cónsules. Para facilitar su trabajo, cada maestro mayor de todo barco o fusta debía recaudar cada sábado de los cofrades que para él trabajasen las capitaciones semanales, que luego ese día, o el domingo siguiente, entregaría a uno de los cónsules. Cuando alguno de estos maestros de hacha partía de viaje debía disponer que las cuotas semanales les fuesen debidamente entregadas el sábado a los cónsules, de lo contrario a su regreso debía satisfacer todos los atrasos. Además, para correr con los gastos, se estableció la conveniencia de que cada cofrade estableciese voluntariamente alguna donación en favor de la cofradía, en su testamento. Unas cláusulas similares se contienen entre las ordenanzas de los barqueros de 1380, pues prevén las donaciones testamentarias voluntarias y el pago de las cuotas a la cofradía por los barqueros que partiesen de viaje; los cuales serían atendidos de los bienes de la almoina en caso de que durante el mismo lo necesitasen, a criterio de los cuatro administradores y de cinco hombres buenos de la misma.

Cualquiera, hombre o mujer, aunque fuese ajeno al oficio, podía ingresar en la cofradía de los estibadores barceloneses, siempre que no viviese en concubinato o comerciase con su cuerpo. Para correr con los gastos de la misma se establecían derramas. Los que no contasen con medios debían contribuir con lo que podían, cada semana o cada mes. Entre las ordenanzas de la cofradía de marinos y pescadores de Tortosa, instituida para el rescate de cautivos, se recoge que sus miembros debían dejar donativos a la asociación entre sus mandas testamentarias. Las ordenanzas de la cofradía de marinos de Coplliure establecen que cualquier 
patrón de la localidad que navegase por su costa, o los forasteros que lo hiciese en naves de Coplliure, aunque no perteneciesen a la misma, debían abonar a la caja de ésta 2 dineros por libra de mercancía transportada. Con lo recaudado se harían dos tortas de 50 libras de cera cada una, para que ardiesen durante las fiestas, los domingos y los sábados delante del altar de la Virgen, en las misas mayores; también una linterna debía estar encendida día y noche en dicho altar; además, debían arder 4 cirios de 4 libras de cera cada uno delante del Cuerpo de Cristo cuando fuese sacado en procesión por la villa.

Por lo que respecta a las cofradías valencianas, los privilegios emitidos por Jaime II autorizando la constitución de las de calafates, marinos y pescadores, que como vimos son casi idénticos, contemplan la posibilidad de que en las mismas se cobrasen cuotas entre sus miembros con fines funerarios y píos. Las ordenanzas de la cofradía de calafates de 1392 contemplan la posibilidad de que los mayorales expulsasen a aquéllos que no contribuyesen en las misiones de la almoina.

Las de los pescadores de San Andrés y las de marinos de San Esteban, también del año 1392, son muy similares entre sí por lo que las analizaremos conjuntamente. Las primeras consignan que todos los que fuesen admitidos en la cofradía debían ser hombres de buena fama y pagar de entrada 2 sueldos para su caja. Mientras que en la segunda podía entrar, además de los hombres y mujeres de mar, cualquiera de cualquier oficio o estamento, en número máximo de 200 cofrades, siempre que fuesen, del mismo modo, fieles cristianos y no pecadores, y tras pagar 1 florín de oro a la caja si se afiliaban en vida, o 2 si lo hacían tras su muerte; siempre que no fuesen pobres, en cuyo caso serían admitidos a criterio de los mayorales, a los que los nuevos miembros debían prometer fidelidad. Los familiares de los cofrades (hijos o hijas) así como sus servidores («macips» o «macipes») que viviesen en sus casas y tuviesen suficiente fortuna debían abonar, asimismo, los 2 florines de entrada postmortem.

La cofradía de pescadores debía mantener una lámpara delante del altar de $\mathrm{S}$. Andrés o en otra iglesia que estimase oportuna, que ardiese día y noche y fuese pagada de los dineros de la caja. Las cuotas de entrada de los marinos tenían como destino atender a los cofrades pobres y otras obras caritativas y piadosas, mientras que las multas en cera se destinarían a las luminarias de la misma en honor de S. Esteban. Por su parte, los pescadores debían confeccionar dos cirios de cera de cuatro libras cada uno, asimismo para el altar de S. Andrés, o donde fuese dicha la misa del sábado en honor de la Virgen, que serían renovados en vísperas de la fiesta del santo y utilizados en las distintas misas en honor de la Virgen. Algo similar a lo dispuesto por los marineros, que tendrían cirios o blandones de cera, con los símbolos del oficio, para que ardiesen en la capilla de su patrón durante las misas celebradas los días de fiesta.

Como los barqueros barceloneses, los pescadores valencianos se debían reunir una vez al año en su sede gremial conventual para comer, pagando las contribuciones que estimasen oportunas los prohombres. Al día siguiente se haría en 
dicho convento un aniversario general por las almas de sus padres y de los cofrades difuntos, en el cual serían cantadas 2 misas de réquiem y arderían 4 cirios de 3 libras cada uno. Además, debían celebrar otras 4 reuniones anuales: una el domingo tras Navidad, otra el posterior a Pascua de Resurrección, el posterior a S. Juan y el posterior a S. Miguel, para tratar los asuntos de la almoina y para pagar cada uno 12 dineros con destino a la caja; con los que sufragar los gastos antedichos y hacer obras de caridad, como atender a pobres vergonzantes, vestir huérfanos o rescatar a los miembros caídos en poder de sarracenos $u$ otros piratas. En dichos capítulos serían leídas las ordenanzas de la cofradía, para conocimiento de todos. Los días de capítulo no se podía trabajar. El que faltase al primero del año sería perdonado, si faltaba al segundo sería amonestado por los mayorales, y si lo hacía al tercero, expulsado de la cofradía y privado de sus beneficios. Si el expulsado quería ingresar de nuevo en la almoina debía pagar la tasa de entrada, 2 sueldos, así como todo lo que había dejado de abonar de los capítulos anteriores. Todos los nuevos miembros serían recibidos en uno de estos capítulos generales, en presencia de los restantes cofrades, y allí pagarían su cuota de ingreso. Mientras que en la otra cofradía de pescadores valencianos, la de la Virgen de la Bona Via, sita en una capilla edificada en la casa del gremio, cada pescador, de los que voluntariamente pertenecían a la hermandad, debía abonar dos dineros cada domingo, cuando acudiesen a la misa dominical. Lo recaudado por esta vía, y mediante las multas, servía para sufragar los ornamentos de la capilla y las misas ordinarias, así como para pagar los rescates de los hermanados cautivos y subvenir las necesidades de los enfermos. La mitad de las multas por trabajar en días festivos tenía como destino las arcas reales, mientras que un tercio de las restantes penas se debía destinar, anualmente, al bayle general. Los nombres de los socios debían constar en un libro en poder del clavario.

Por su parte, los marinos de S. Esteban también celebraban una colación anual, en el convento de los frailes predicadores, a la cual debían acudir todos los cofrades, a no ser que contasen con licencia de los mayorales para ausentarse. Cada asistente pagaba a escote lo que le correspondía en dicha comida. Los que no asistiesen, por vejez $u$ otro impedimento, debían igualmente pagar su parte de los gastos de la pitanza, pero podían enviar en su lugar a un pobre de su elección para que participase en la misma. Antes del festín, los frailes, que estaban convidados al mismo, debían decir una misa. Al día siguiente, o en los sucesivos, dichos frailes, en el citado convento y en presencia de todos los cofrades, cantarían otra misa de aniversario por el alma de los cofrades difuntos, mientras que en el plazo de 10 días cada cofrade debía rezar 50 padrenuestros con idéntico fin. Tras la misa de aniversario, la cofradía de marinos celebraba su capítulo general, en el citado convento, en el cual eran elegidos los nuevos mayorales de la siguiente anualidad. Asimismo, podían celebrar cuantos capítulos estimasen oportunos, para tratar los asuntos de la cofradía. Como en el caso de los pescadores, los nuevos cofrades de $\mathrm{S}$. Esteban solamente podían ingresar en la cofradía en uno de estos capítulos generales, con el consentimiento de la mayoría de sus com- 
ponentes, pagando las preceptivas cuotas de entrada y prometiendo obediencia a sus ordenanzas. Para salir de la almoina era preciso hacerlo, del mismo modo, en uno de estos capítulos generales, y tras haber satisfecho todas las cuotas, pagos y multas que quedasen por abonar. Los cofrades pecadores, además de multados, podían ser expulsados de la cofradía. Aparte de los florines de la entrada, una de las cuotas de ingreso más abultadas, como correspondía a un oficio de empresarios con importante patrimonio, los asociados debían abonar 4 sueldos anuales, en 2 plazos de 2 sueldos cada uno, con destino a los cofrades empobrecidos u otros gastos de la cofradía.

Como casi todas las cofradías, la de Santa Catalina de calafates de Barcelona realizaba en la festividad de su patrona una misa general de aniversario por el alma de todos los difuntos. Ese día, además, tenían lugar la elección de los órganos rectores y otras cuestiones organizativas. De este modo, eran elegidos los cónsules del arte, esto es, los encargados de regir el gremio además de la cofradía. Se trataba de dos hombres del oficio o arte que debían desempeñar la función rectora durante un año, cuyo cometido era hacer cumplir a los restantes las normas contenidas en las ordenanzas. Los cuales, una vez elegidos por el oficio, debían jurar ante el bayle de Barcelona que desempeñarían su función correctamente y sin parcialidad o fraudes, siendo provechosos al arte, a los patrones de los barcos y a la cosa pública. Esos mismos día y hora debían ser elegidos dos prohombres del arte con la misión de custodiar las llaves de la caja de la cofradía, quienes igualmente debían jurar ante el bayle. Los mismos, junto a los cónsules, debían administrar los dineros de la caja y gastarlos en las cosas necesarias a la cofradía, según su conciencia. Pero si para los gastos necesarios no hubiese fondos, los cónsules y prohombres reunirían a los cofrades para colectar lo necesario. Los cónsules y prohombres salientes tenían que hacer entrega de las llaves a los entrantes y rendirles cuentas de su administración, lo cual debían poner por escrito, lo mismo que los administradores de los barqueros. Si alguno de los cónsules o prohombres de los calafates, por enfermedad o viaje, no pudiese entender en algunas de las funciones de su cargo podía poner a otro en su lugar, el cual gozaría del mismo poder y debería prestar idéntico juramento. Cuando los cónsules precisasen consejo de algunos hombres buenos del arte, o consultar a los restantes sobre aspectos de la normativa, podían reunir a los miembros del mismo, que debían acudir a la hora indicada, so pena de media libra de cera o 12 sueldos para el cirio del arte o para la citada caja.

En 1459 las ordenanzas de los barqueros nuevos establecen, en primer lugar, la facultad de la cofradía de reunirse en su sede gremial, el monasterio de S. Francisco, en todo momento y conforme a ellos bien visto les fuese. Los órganos rectores de esta cofradía eran elegidos en una reunión de sus socios celebrada el domingo siguiente a la festividad de San Bernabé de junio, en la cual los barqueros nuevos elegirían a sus dos prohombres, tal y como estaba determinado por la ciudad. Además, debían designar a 4 administradores, dos de ellos patronos de bar$\mathrm{ca}$, y otros dos no, pero que contasen con casa en la ciudad y no hubiesen sido es- 
clavos o descendientes de ellos. Pasados 4 días de su elección, los citados patronos debían jurar ante el veguer o el bayle observar las ordenanzas de la cofradía.

De lo antedicho, y de lo que a continuación veremos, se desprende que, según sus ordenanzas, se confundía la cofradía de calafates de Santa Catalina, como institución religiosa, caritativa y mutualista, a la que podían pertenecer los familiares y los asalariados de los artesanos, con el gremio o arte, como institución económica y laboral que daba cabida solamente a los maestros titulares de un taller de la profesión, o empresarios con negocio propio. En menor medida ocurre otro tanto con la cofradía de los barqueros nuevos.

Similares a las barcelonesas fueron las formas de elección de los cargos rectores de las cofradías valencianas. Los privilegios de constitución de las de calafates, marinos y pescadores contemplan la posibilidad de elegir entre ellos dos hombres buenos, o más, para regirlas con acuerdo de sus miembros o de la mayor parte de ellos, en su beneficio y del oficio. Además, cuando se juntaban $10 \mathrm{o}$ más hombres de cada una de las cofradías podían estatuir aquellas ordenanzas lícitas y honestas que estimasen oportunas. Sin embargo, ni las ordenanzas de los pescadores de S. Andrés ni las de los calafates de 1392 dicen nada al respecto; si bien estas últimas sí contienen una cláusula que dispone que aquellas ordenanzas aprobadas por la cofradía que fuesen buenas y honestas fuesen luego ratificadas por el rey y sus lugartenientes. Por su parte, los marineros de S. Esteban, como vimos, elegían a sus dos mayorales anuales en el capítulo general celebrado, tras la pitanza colectiva, el día de la misa de aniversario de difuntos. Los salientes debían rendir, en el plazo máximo de 15 días y bajo pena de 10 libras de cera, cuentas a los entrantes, poniéndolos al día de los haberes de la cofradía, para lo cual debían recaudar las cuotas, penas y derramas pendientes de su ejercicio. Para tal fin, poner al día las cuentas y recaudaciones, los mayorales, entrantes y salientes, podían disponer de 10 sueldos de la caja de la cofradía. Junto a los mayorales, la cofradía de marineros disponía de «enviados» («misatges»), una especie de funcionarios con tareas diversas. Entre las que se encontraban las de convocar a los cofrades a los funerales y otros actos, por lo que cobrarían 2 sueldos por la sepultura de personas mayores, 1 por las restantes; encargarse de los pagos a los pobres y otros sostenidos con los fondos de la cofradía; o cobrar las multas a los cofrades, que si se resistían serían multados con 2 libras de cera, cumpliendo las órdenes de los mayorales y del gobernador, en cuyo nombre actuaban, y cobrando como salario de cada sanción 4 dineros. Como vemos, estos funcionarios realizaban las tareas que en otras cofradías desempeñaban sus figuras rectoras, como los mayorales, pero que en este caso, debido probablemente a que éstas pasaban mucho tiempo fuera de la ciudad, embarcados en las travesías de sus barcos, eran sustituidas por asalariados delegados suyos, que por su trabajo, aparte de las tasas antedichas, percibían, cada uno, un sueldo anual de 1 florín. Como los calafates valencianos, también los marinos, en sus ordenanzas de 1392, contemplaron la posibilidad de reformar sus estatutos como bien visto les fuese, siempre aten- 
diendo al bien público y con autorización del gobernador del reino. Mientras que en las de pescadores de la Virgen de la Bona Via se dispone que el siguiente domingo al día de la pascua de Resurrección, festividad de la citada Virgen, en la capilla del gremio se procedería a la elección, entre los hermanados, de un clavario y tres administradores, encargados de velar porque se guardasen las festividades, denunciando a los contraventores ante el síndico y jurados del Común. Las multas se guardaban en la caja de la cofradía junto a las contribuciones de los miembros, que custodiaba el clavario en su casa. La cual contaba con tres llaves, cada una en poder de un administrador, y sólo podía ser abierta en presencia de los cuatro cargos de la hermandad. Cuando los gastos u ornamentos de la capilla superasen los 100 sueldos, éstos debían contar con la autorización de la mayor parte de los hermanados. Tanto el clavario, como los administradores, una vez cumplida su gestión, debían dar cuenta ante los nuevos cargos electos, en los dos días siguientes a su elección, o de lo contrario los entrantes podían exigírsela ante el bayle.

Por su parte, en la cofradía para el rescate de cautivos hecha por los marinos y pescadores de Tortosa, se debían elegir 4 clavarios encargados de administrar el dinero de las cuotas de sus miembros, así como el dejado en los testamentos y últimas voluntades para dicho fin.

\subsection{Aspectos sociales}

Las ordenanzas de los barqueros barceloneses de 1380 son las primeras que reglamentan con minuciosidad estos cometidos, y parecen ser la fuente de inspiración para las de los otros oficios redactadas con posterioridad. Así, disponen que cuando muriese uno de sus cofrades, o bien su mujer o uno de sus hijos, los restantes de la almoina debían acudir a su entierro, salvo si tenían justa excusa, bajo pena de una libra de cera, si se trataba del entierro de un adulto, media en el caso de un bebé. Una vez producido el deceso, los familiares del difunto debían comunicarlo a los hombres buenos de la almoina, los 4 administradores y los 2 encargados de la bolsa, quienes informarían a los restantes cofrades, en pena de una libra de cera. Todos los inscritos en la almoina debían rezar por el alma del finado 30 padrenuestros y 30 avemarías; en pena de 2 dineros, por amor de Dios y el alma del difunto. Por la cual se debían, asimismo, decir 10 misas tras el entierro, en la iglesia de S. Agustín, donde estaba la capilla de la almoina. También en su recuerdo se debía dar de comer a 5 pobres, por amor de Dios y en evocación de las 5 llagas de Cristo, pagándose a cada uno 8 dineros para la comida.

Las ordenanzas de los calafates barceloneses de 1392 parecen inspiradas en las de los barqueros a la hora de regular los funerales de los socios de su cofradía. En las cuales, la primera finalidad concreta de orden social a la que hacen referencia es la funeraria. Cuando uno de los cofrades fallecía todos los restantes debían acudir a su entierro, siendo bastante que lo hiciese el cabeza de familia de cada casa; aunque si éste se encontraba ausente, en el bosque (en busca de ma- 
dera) o de viaje (a bordo de un barco), debía ser sustituido por su mujer; si alguno de los cofrades, o su mujer, no pudiese acudir por justo impedimento, sería creído por su juramento; la pena por inasistencia injustificada quedó fijada en media libra de cera o 6 dineros. Cada cofrade debía rezar 30 padrenuestros y otras tantas avemarías por el alma del finado, si no, pagaría 2 dineros o una limosna a voluntad. Los gastos del aniversario de 10 misas en honor del alma del difunto serían sufragados mediante colecta o de la caja de la cofradía. Al mismo debían acudir los cofrades que pudiesen y los cónsules del arte, y tendría lugar durante la primera fiesta que hubiese entre semana después de que el cuerpo fuese enterrado. El día del entierro, en honor del alma del difunto, así como por reverencia de las 5 llagas de Jesús, se daría a 5 pobres de comer, o 6 dineros para la comida, a cargo también de la caja. Estas exequias, rezos y limosnas serían asimismo hechos por los cofrades muertos fuera de Barcelona, en aquella parroquia donde yaciese su cuerpo. Por el contrario, por los barqueros fallecidos fuera de Barcelona los restantes de la almoina debían decir sus oraciones en la misma iglesia de S. Agustín donde estaba su capilla.

Lo mismo se puede apuntar con arreglo a las ordenanzas de los pescadores valencianos de $\mathrm{S}$. Andrés, también de 1392 . Todos los cofrades y cofradesas tenían la obligación de acudir ante la sepultura de un compañero finado, a rezar 50 padrenuestros y otras tantas avemarías, por el alma del difunto, para que Jesucristo le perdonase los pecados, vistiendo los capuchones que los mayorales les ordenasen. Igual se debía hacer cuando muriesen la mujer, hijo o hija menores de 10 años de algún cofrade. También debían acudir cuando un cofrade casaba a un hijo o hija, o los ingresaba en un convento. Del mismo modo se podían beneficiar de las prestaciones de la cofradía los pescadores forasteros que contribuyesen a la misma. Por su parte, las ordenanzas de los marinos valencianos, de ese mismo año 1392, estatuyen que los enviados o mistages debían avisar a los cofrades para que acudiesen a los entierros de sus compañeros difuntos, así como de sus mujeres, hijos, macips y de todos cuantos viviesen en sus casas, y también de aquellos pobres que fuesen enterrados por la cofradía como obra de caridad. Esta asistencia a los sepelios incluía el acompañamiento de los féretros desde la casa del difunto hasta la fosa, y desde ésta se debía retornar a la casa del finado; si se ausentaban sin licencia de los mayorales, serían penados con una libra de cera con destino a las luminarias del patrón de la cofradía. Bien ante la tumba, o durante los siguientes 10 días posteriores al entierro, los cofrades debían rezar 50 padrenuestros por el alma del fallecido y de los restantes difuntos. Mucho más parcas a este respecto son, sin embargo, las ordenanzas de los calafates de Valencia, también de 1392, que únicamente estatuyen que los mayorales de la almoina pudiesen ordenar a sus miembros, bajo pena de una libra de cera, que acudiesen al entierro de los finados de la misma.

Por su parte, los barqueros nuevos de Barcelona dispusieron entre sus ordenanzas de 1459 la obligación de los cofrades de acudir a las honras fúnebres de los adultos o niños fallecidos, en pena de 8 dineros por los primeros y de 4 por los 
segundos, con destino a la caja de la cofradía. Si un cofrade estibador barcelonés muriese a dos leguas de Barcelona y su familia no tuviese medios para trasladar el cuerpo, los restantes debían ir a buscarlo con cirios, para enterrarlo tal y como mandasen los regidores y administradores de la cofradía.

Los barqueros barceloneses estatuyeron en 1380 que de los dineros comunes se comprasen o fuesen hechos dos paños fúnebres bellos, uno con destino a los cuerpos de los adultos y el otro al de los niños. Igualmente dispusieron la existencia de tres fosas cubiertas con losas y un osario en su capilla de S. Agustín, que sirviesen de sepultura a los miembros de la almoina que así la eligiesen. Probablemente inspirados en estas disposiciones, los carpinteros de ribera de esa ciudad dispusieron que de la caja de la cofradía se debían adquirir también aquellos objetos como cirios o paños que fuesen precisos para las actividades de la cofradía. Tal y como pasó con los pescadores y marinos valencianos. En la cofradía de los primeros, para acompañar al cuerpo de Cristo, en los entierros de los cofrades, debían ser hechos dos cirios cada año, reparados y repuestos tantas veces como fuese necesario, y luego guardados por el andador en la caja de la cofradía. Si algún difunto no miembro de la cofradía dejaba dinero a la misma en su testamento, 50 sueldos si era mayor de 20 años, 30 si era menor, los cofrades acudirían a su entierro llevando su cama y paño fúnebres, y rezando las mismas oraciones que por los cofrades difuntos. Los mayorales no podían prestar la cama y paños fúnebres de la cofradía a los que no fuesen cofrades. Ni tomar dineros de la caja. Las ordenanzas de la cofradía de los segundos, los navegantes, disponen que se comprasen al menos dos cajas, una para guardar los dineros y ahorros de la misma, cuya llave estaría en poder de uno de los mayorales; la otra para contener los paños de seda, terciopelo y oro con destino a los funerales, que debían ser reparados o renovados cada vez que fuese preciso, la cual se guardaría en casa del otro mayoral, junto con la cama y otras cosas necesarias para llevar los cuerpos de los finados.

Por lo que se refiere a los aspectos mutualistas, si un cofrade o cofradesa de la cofradía de los calafates barceloneses caía en la pobreza o enfermedad, los cónsules del arte y los prohombres regidores de la caja debían socorrerlo de los dineros de la misma, según su criterio; tanto para comida como para pagar médicos y medicinas, y otras cosas necesarias. Si este cofrade pobre fallecía, su sepultura sería igualmente sufragada de los dineros de la caja de la cofradía. Algo similar se haría con los barqueros barceloneses. A los que su sepultura les era costeada del dinero de su almoina. De donde también serían pagadas sus deudas. En el caso de los enfermos, los 4 prohombres administradores de los barqueros barceloneses debían ordenar que al que se encontrase mal tenían que velarlo dos o tres personas de la almoina cada noche, que serían relevadas por otras, hasta que el enfermo mejorase o falleciese, salvo que el mismo prefiriese ser velado por sus amigos. Mientras que si algún miembro de la cofradía de pescadores de $S$. Andrés de Valencia, por enfermedad, tuviese necesidad de ayuda los hombres de la misma, designados por los mayorales y según comunicación del andador, le visitarían y ve- 
larían de dos en dos, y sus necesidades serían sufragadas del dinero de la caja. Como hemos dicho más arriba, los diplomas mediante los cuales Jaime II aprobó la constitución de las cofradías de calafates, marinos y pescadores de Valencia, casi idénticos como ya vimos, disponen que la finalidad de las mismas eran fines píos, compra de cera, y funerarios, atender a los difuntos, así como conceder subsidios a los miembros del arte que cayesen en la pobreza. Este respecto es más largamente desarrollado por las ordenanzas de los marinos de 1392, que disponen que las tasas de entrada en la cofradía, así como las cuotas anuales pagadas a ésta, servirían para subvenir las necesidades de los cofrades pobres, así como para otros actos piadosos y caritativos de la misma. Si algún cofrade caía en pobreza, o era capturado por piratas, la cofradía debía socorrerlo, ocupándose de su sustento o de su rescate, para lo cual se emplearían los fondos de la misma o aquellas derramas distribuidas entre sus miembros que fuesen acordadas por la mayor parte de los mismos.

Volviendo a los calafates barceloneses, otro aspecto mutualista era el de correr con el rescate de todo cofrade cautivo por musulmanes o malas gentes, el cual se pagaría también de la caja, por parte de los cónsules y los citados prohombres, con consejo de cuatro de los cofrades más antiguos. Cometido éste exclusivo de la cofradía de marinos y pescadores de Tortosa y de la de marinos de Barcelona, como ya vimos. También, como hemos dicho más arriba, lo recaudado en la germanía de la Virgen de la Bona Via valenciana tenía como destino, aparte de los ornamentos y las misas, pagar los rescates de los hermanados cautivos y subvenir las necesidades de los enfermos. Cosas similares han sido dichas, asimismo, de los otros pescadores de los que aquí hemos hablado, los barceloneses, de los que apenas quedan otras noticias.

Los barqueros barceloneses perfeccionaron su sistema de protección durante el siglo XV, con una serie de ayudas para casos de vejez o enfermedad. Si uno de ellos se veía incapacitado para acudir al trabajo por enfermedad contraída durante el ejercicio de la profesión podía seguir cobrando su salario de la caja de la cofradía, sin limitación de tiempo, hasta que estuviese bien curado, siempre que el enfermo estuviese en Barcelona. El control del estado físico era ejercido por los 4 prohombres administradores, pero no se ayudaba a aquéllos que recayesen en la misma enfermedad. El sistema no se vio exento de abusos, para evitar los cuales, a principios del siglo XVI se ordenó que quienes pudiesen tenerse en pie acudiesen al trabajo ayudando en la medida de sus posibilidades a sus camaradas. Las ayudas a ancianos e impedidos, que también cobraban el salario completo, atendían a las mismas razones: porque habían agotado sus cuerpos en el ejercicio del oficio durante toda su vida, y por tanto iban destinadas a aquéllos cuyo deterioro físico les impedía trabajar (Bonnassie, P., 1975:130-131). La cofradía valenciana de pescadores de $\mathrm{S}$. Andrés correría con los gastos de los asalariados de los pescadores que fuesen miembros de la misma y estuviesen necesitados, si cayesen en la enfermedad o muriesen. 
Por su parte, de la caja de la cofradía de los barqueros nuevos de Barcelona se pagaban los daños y desfalcos causados por los mismos en el ejercicio de la profesión a las mercancías que cargaban o descargaban. Y también, tal y como hemos visto para los otros barqueros, las ayudas necesarias para los cofrades que cayesen en la enfermedad, al igual que los dispendios con destino a limosnas, luminarias y otras obras pías. Más concretamente, los barqueros nuevos que tuviesen casa en la ciudad y fuesen socios de la cofradía más de tres años, y que hubiesen trabajado con los restantes barqueros por el mismo período, si enfermaban podían seguir cobrando su salario a consideración de los prohombres y administradores de la cofradía. Del mismo modo, al igual que los barqueros de S. Pedro, los nuevos o de Santa María, debían entregar parte de las ganancias por su trabajo a la cofradía. De este cometido se encargaba el administrador «levador», quien anotaba cuanto descargaba o cargaba cada barquero y lo que le correspondía de ganancia, para entregar luego todos los salarios a los prohombres del oficio o cofradía. Los cuales debían llevar la cuenta de cuanto se ganaba en la ribera (carga y descarga), controlando a los «levadores». Luego serían repartidas estas ganancias entre todos los barqueros. Incluidos los patrones de barca que por enfermedad no pudiesen trabajar, siempre que su embarcación fuese pilotada por otro, si no el gremio pondría un patrón, que por ello percibiría un cuarto de la ganancia de la barca. Para mayor igualdad entre cofrades, se dispuso que cada patrón pudiese tener solamente una barca grande y otra pequeña.

\subsection{Aspectos económicos}

Antes hemos hablado de quiénes podían ingresar en la hermandad de Santa Catalina, todos aquellos relacionados con los maestros calafates barceloneses. Pero la pertenencia a la cofradía remarcaba además la emancipación profesional, pues el ingreso de los nuevos maestros debía efectuarse el mismo día que dejaban de ser asalariados de otro maestro y se establecían por su cuenta. Por lo que se refiere a estos asalariados o criados, una de las ordenanzas dispone que si alguno dejaba a su maestro antes de cumplido su contrato, ningún otro maestro podía emplearlo sin consentimiento del primero, bajo pena de 10 sueldos por cada vez, la mitad para el rey o para el bayle real de Barcelona, la otra para la caja de la cofradía. Los maestros jóvenes no podían ser desplazados por los experimentados de las obras que realizasen. En todo caso se les pagaría el salario que estimasen el maestro mayor de la construcción y los cónsules, en función del trabajo que realizasen.

En caso de disputa entre dos miembros del arte, los cónsules darían cuenta al bayle, quien, habida información, pondría paz entre ellos, bien por vía de sanciones o de acciones judiciales. Además, el bayle juzgaría y castigaría a los artesanos que le fuesen llevados por los cónsules. De dichas penas, la mitad sería para el rey o el bayle, y la otra para la caja de la cofradía. 
Cuando un maestre de navío quisiese reparar su nave podía tomar como maestro mayor o director de la obra al maestro de hacha o calafate de su elección. Después debía acudir a los cónsules del arte en demanda de los restantes maestros calafates, quienes le proporcionarían tantos como fuesen necesarios. Pero, en caso de que no hubiese bastantes, le darían simples obreros. Si los patrones de naves no quedaban satisfechos con los artesanos que les proporcionasen, queriendo más o de procedencia foránea, los cónsules podían cambiarlos, dejando trabajar a extranjeros en la obra, siempre que no fuese en mayor número que los locales, que se situasen bajo su autoridad, como éstos, mientras durase la obra, y siempre que corriesen con las mismas cargas y obligaciones que los calafates barceloneses, caso de los trabajos forzados para el rey, la Generalitat o la ciudad; con pena de 5 sueldos por cada día, recaudada por los cónsules y repartida por mitad entre el rey y la cofradía. También los forasteros debían contribuir a la caja del arte, mientras trabajasen en la ciudad, como lo hacían los locales en sus poblaciones cuando a ellas iban a trabajar. Los salarios de los maestros, locales y forasteros, y sus mozos asalariados, debían ser acordados entre los cónsules y los maestros mayores de cada obra, con consentimiento del patrón del navío. Cada maestro podía emplear como máximo un asalariado por obra, si el patrón del navío no quisiese más, con pena de 5 sueldos por día; mientras que por su parte el patrón no podía echar de la obra al empleado de cada maestro. Si algún maestro enfermaba y no podía acudir a trabajar, los cónsules podían dar permiso a su empleado para que continuase los trabajos que considerasen que estaba capacitado para hacer, de modo que no perdiese su tiempo y su maestro se pudiese sostener con lo que ganase su empleado. Cuando en alguna obra su maestro mayor fuese forastero no podía ser cambiado por otro maestro mayor sin el consentimiento del patrón de la nave, y con conocimiento de los cónsules y cuatro hombres buenos del arte elegidos por los mismos; con pena de 5 sueldos por día, repartida como ya se ha dicho, no obstante lo establecido en el Libro del Consulado de Mar. Cuando era comenzada una obra, y el navío debía partir antes de que ésta fuese terminada, el patrón del barco o el maestro mayor de la misma podían pedir a los cónsules que les proporcionasen maestros de hacha para finalizarla, es de suponer que embarcados en la nave. Si no había tantos como fuesen necesarios, el maestro mayor, a consejo de los cónsules, podía hacerlos venir de fuera. Pero para las restantes obras de ese patrón debían ser empleados maestros locales, siempre que fuesen suficientes.

Con respecto a la materia prima, para evitar discusiones, los calafates dispusieron que se mantuviese la costumbre de que la leña que se hiciese el viernes sería del maestro que la cortase, mientras que la del sábado sería para el maestro mayor de la obra, mientras que la leña de miembros sería del maestro que la hacía. Por su parte, el patrón de la nave debía dar los cordeles, herramientas y otras cosas acostumbradas.

Como hemos visto para los calafates de Barcelona, tampoco los de Valencia, según sus ordenanzas de 1392, podían ser obligados a trabajar en obra alguna, a no ser que fuese en las embarcaciones reales. 
En los privilegios de Jaime II aprobando la constitución de las cofradías de calafates, marinos y pescadores de Valencia, de 1306 y 1308, una cláusula dispone que cuando surgiese discordia entre los asociados o entre alguno de ellos y alguien de fuera de la cofradía, ésta era competente para intentar poner de acuerdo a las partes. Nada se aclara, sin embargo, con arreglo al ámbito de actuación de estos tribunales arbitrales, si social, relativo a aspectos religioso-asistenciales, o económico, a otros de tipo profesional-laboral. En este mismo sentido se extienden las ordenanzas de los marinos de 1392, que disponen que cuando surgiese algún debate o disputa entre los miembros de la cofradía, o entre éstos y alguien de fuera de ella, los mayorales debían trabajar para poner de acuerdo a las partes, mediante consejos y amonestaciones, que si no eran atendidos por los afiliados podían ser expulsados de la asociación.

\section{CONCLUSIÓN}

Como se aprecia en las páginas precedentes, los gremios de los oficios relacionados con actividades marítimas se organizaron en cofradías con fines religiosos, funerarios y mutualistas, que en algunas ocasiones extendieron sus atribuciones a nivel gremial y corporativo. Pero cuando estos oficios sintieron la necesidad de regular su profesión en aspectos económicos y laborales diferenciaron entre la cofradía como órgano de previsión, y el gremio o arte, como órgano de regulación del oficio. Sobre todo a partir del siglo XV, cuando estas últimas necesidades fueron crecientes y ya se habían consolidado las cofradías como mecanismos de protección, pero quedaban importantes aspectos que regular en materia corporativa.

\section{BIBLIOGRAFÍA}

BENÍTEZ BOLORINOS, M. (2006): Las cofradías medievales en el Reino de Valencia (1229-1458), Alicante.

BENÍTEZ BOLORINOS, M. (2006): «Las cofradías en el reino de Valencia: análisis y claves interpretativas», Anuario de Estudios Medievales, 36, 2.

BOFARULL Y DE SARTORIO, M. DE (1876): Gremios y cofradías de la antigua Corona de Aragón. Colección de documentos inéditos del Archivo General de la Corona de Aragón, XL, Barcelona.

BOFARULL Y SANS, F. DE (1910): Gremios y cofradías de la antigua Corona de Aragón. Colección de documentos inéditos del Archivo General de la Corona de Aragón, XLI, Barcelona.

BONNASSIE, P. (1975): La organización del trabajo en Barcelona a fines del siglo XV, Barcelona.

BORRÁS I GÓMEZ, J. Y VICTORIO I ALSINA, M. (1990): «Els oficis de la mar al segle XIV: un exemple concret de Funcionament la coca Sant Antoni», XIII Congés d'Historia de la Corona d'Aragó, vol. II, Palma de Mallorca.

CAPMANY, A. (1933): Historial del gremi de bastaixos de capçana i macips de ribera de la duana de Barcelona, Barcelona.

CAPMANY Y DE MONTPALAU, A. DE (1779): Memorias históricas: sobre la marina, comercio y artes de la antigua ciudad de Barcelona, Madrid. Reedición, Barcelona, 1961.

CAPMANY Y DE MONTPALAU, A. DE (1990): Libro del Consulado del Mar, Barcelona.

CARUANA TOMÁS, C. (1954): Estudio histórico y jurídico de la Albufera de Valencia. Su régimen y aprovechamientos desde la Reconquista hasta nuestros días, Valencia. 
DEYÁ BAUZÁ, M.J. (2005): «La pesca en el reino de Mallorca en los siglos XV y XVI. Elementos básicos para su estudio», XVIII Congrès Internacional d'història de la Corona d'Aragó, Valencia.

DURÁN Y SANPERE, A. (1959): «Los barqueros de la playa de Barcelona en los siglos XIV y XV», Divulgación Histórica de Barcelona, 9.

ENSENYANT PUJOL, G. (1991): «Notes sobre els primers gremis i confaries coneguts a Mallorca (segles XIII-XIV)», La manufactura urbana i els menestrals (ss. XIII-XV). IX Jornades de d'estudis historics locals, Palma de Mallorca.

FOGUET MARSAL, J. (1923): Cofradías-Gremios, especialmente fluviales, de la ribera del Ebro en Tortosa, Madrid.

FONT RIUS, J.M. (1990): «Prólogo» de Libro del Consulado del Mar, ed. A. de Capmany y de Montpalau, Barcelona.

FREIRE MOLINER, M.J. (1995): El libro registro de los privilegios de la Albufera de Valencia, Zaragoza.

GONZÁLEZ ARCE, J.D. (2006): «Las formas de organización de los oficios relacionados con el mar en la Barcelona medieval (siglos XIII-XV)», III Congrés D'Historia Marítima De Catlunya, Barcelona.

GONZÁLEZ ARCE, J.D. (2007): «Las cofradías de pescadores de Valencia, siglos XIII-XV», Sociedad Española de Estudios Medievales, Congreso: La pesca en la Edad Media, Santiago de Compostela.

GONZÁLEZ ARCE, J.D. (2008): «Asociacionismo, gremios y restricciones corporativas en la España medieval (siglos XIII-XV)», Revista de Historia Económica, 10.

GONZÁLEZ DÍEZ, E. (1994): «El Consulado de Burgos en la Historia del Derecho. Sobre el concepto e implantación del instituto consular», Actas del V Centenario del Consulado de Burgos, II, Burgos.

GUIRAL-HADZIIOSSIF, J. (1989): Valencia puerto mediterráneo en el siglo XV (1410-1525), Valencia.

IRADIEL MURUGARREN, P. (1993): «Corporaciones de oficio, acción política y sociedad civil en Valencia», Cofradías, gremios, solidaridades en la Europa medieval. XIX semana de estudios medievales, Pamplona.

MARTÍN GRANIZO, L. (1950): Apuntes para la historia del trabajo en España, Madrid.

QUETGLAS GAYÁ, B. (1939): Los gremios de Mallorca. Breve estudio histórico-sociológico de los Colegios de Honorables Menestrales que florecieron en Mallorca desde el siglo XIII hasta el XIX, Palma de Mallorca.

RAMÓN FERNÁNDEZ, F. (2001): El ingreso en la Comunidad de Pescadores de El Palmar y la transmisión hereditaria del «redolí», Valencia.

RIERA I MELIS, A. (1993): «La aparición de las corporaciones de oficio en Cataluña (1200-1350)», Cofradías, gremios, solidaridades en la Europa medieval. XIX semana de estudios medievales, Pamplona.

RUMEU DE ARMAS, A. (1944): Historia de la previsión social en España. Cofradías, gremios, hermandades, montepíos, Madrid.

SALCEDO FERRÁNDIZ, S. (1957): Estudio histórico-jurídico de la Albufera de Valencia y de sus aprovechamientos, Castellón de la Plana.

SANMARTÍN ARCE, R. (1982): La Albufera y sus hombres, Madrid.

SANCHO SERAL, M.L. (1925): El gremio zaragozano del siglo XVI: (datos para la historia de la organización corporativa del trabajo en España), Zaragoza.

SANXO, P.A. (1895): “Constitucions de la caxa dels mariners de Mallorques», Boletín de la Sociedad Arqueológica Luliana, 6.

SMITH, R.S. (1978): Historia de los consulados de Mar (1250-1700), Barcelona.

TINTÓ SALA, M. (1992): «Ordinacions dels barquers de la ciutat de Barcelona durant el segle XV», Medievalia, 10.

UÑA SARTHOU, J. (1900): Las asociaciones obreras en España. Notas para su historia, Madrid. 